\title{
Ten minutes with Doctors Adam and Tom Sullivan
}
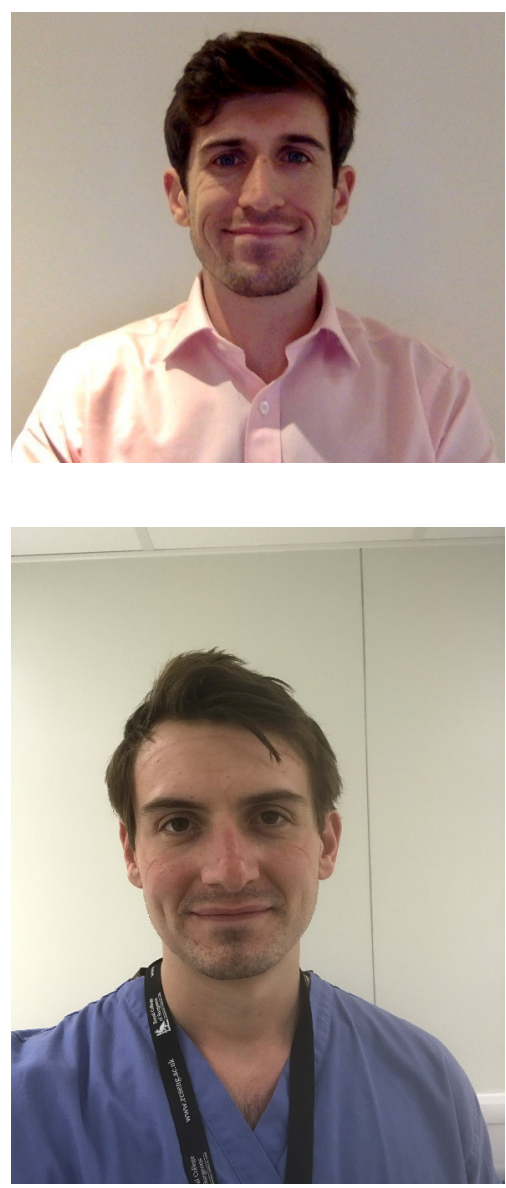

\section{WHAT ARE THE KEY LEADERSHIP MESSAGES YOU WANT TO GET OUT TO THE BMJ LEADER READERSHIP?}

Adam: I would say the key messages are for colleagues to be patient and kind with each other. We are going through an extraordinary event at the moment and the NHS is having to adapt faster than ever in its existence. On the ground, this means significant and evolving changes to our behaviours ranging from interactions with patients and relatives to donning/doffing of PPE and coordinating patient flow. We are all learning as we go and there will be mistakes and disagreements. When these happen we need to support each other.

Tom: Leaders are not expected to have all the answers right away. We all know that this is a situation with no precedent in most of our lifetimes. We know that it is fast moving and that trying to respond and plan (whether day by day, or looking months and years ahead) has myriad unknowns and challenges. Plans will have to change and strong leadership will involve admitting when something is not working. Those making decisions for teams and services should know that they are not expected to always give certainties, but more than ever it is important to communicate clearly and transparently with teams and colleagues about what discussions are being had, what plans are being made and what information is being used to inform these plans.

\section{TELL US A LITTLE BIT ABOUT YOUR LEADERSHIP ROLE AND HOW IT IS CHANGING AS A RESULT OF THE PANDEMIC.}

Adam: I work in acute medicine at a DGH in East London. At the beginning of the outbreak we managed a lot of the first COVID
Biographies

Adam Harvey-Sullivan MB BS MA is a junior doctor living and working in East London. Currently whilst continuing clinical work he is studying for a Masters in Public Health at the London School of Hygiene and Tropical Medicine. He gained a degree in Natural Sciences from the University of Cambridge before going on to qualify in Medicine from Imperial College, London. This August he will start an Academic Clinical Fellowship in General Practice at Queen Mary's University in East London. He has an interest in medical education, health inequalities and the wider social, political and ecological determinants of health.

Tom Sullivan MB BS MA MRCS studied medicine at the University of Cambridge and Imperial College London, qualifying in 2017. He is a Clinical Fellow in general and trauma surgery at a London teaching hospital.

cases on our ward. As it spread through the hospital, I would sometimes be drafted to wards that had just been converted into a new 'COVID' ward. A lot of my work was then guiding staff through changes in behaviour related to managing COVID and communicating what had and had not worked on acute medicine.

One of the challenges we are seeing now is separating 'COVID' and 'non-COVID' patients. Obviously distinguishing between COVID and non-COVID can be tricky so keeping those with low clinical suspicion, particularly those who are vulnerable, shielded from potential COVID patients is important. This creates problems and tensions regarding patient flow.

Tom: I am a clinical fellow in surgery in a London teaching hospital. In late March, I was in the first wave of junior doctors to be redeployed to support the intensive care unit. Over a matter of days, the number of redeployed doctors grew from a handful to many as specialities kept only skeleton crews and redeployed the majority of their junior workforce to help with the growing pressure on ICU. This has been new territory both for the redeployed doctors and for the ICU regulars receiving them. As for many, for me this involved an upheaval from a clearly defined role in a familiar and close-knit team, to working alongside new faces in an unfamiliar environment, to fight a virus that we are learning about as we go. As team members, our first challenge has been to come together as a group of relative strangers, to accept our varied personalities and skill sets, to capitalise on our assorted specialist backgrounds and to form a cohesive team that can serve the unit $24 / 7$.

\section{WHAT EVENTS IN YOUR PAST EXPERIENCE ARE MOST INFORMING YOUR LEADERSHIP IN THIS PANDEMIC?}

Adam: I am currently coming to the end of studying an MSc in Public Health part-time at the London School of Hygiene and Tropical Medicine. Obviously, Public Health has never been more relevant but in terms of my clinical practice, the most important role it has played is managing the 'infodemic'. There is so much information being put out there and often staff can find it very overwhelming. The Masters has helped me be able to appraise critically the information out there and try to communicate clearly what can be learnt and-more often than not-where there are areas of uncertainty.

Tom: My previous experience working in critical care and respiratory medicine has been invaluable in getting up to speed on ICU 
and in helping my other redeployed colleagues as we all adjust to our new roles. It is a tribute to the diversity of experience that is inherent in the UK's postgraduate medical training system

\section{WHAT ARE YOU FINDING THE BIGGEST CHALLENGES?}

Adam: What I have found most difficult is not being able to have a patient's loved ones come to visit them. Not only does it leave the patients stranded but also relatives are often stuck having no idea what is happening once their loved one has been admitted. In addition, we often have to have really difficult and sensitive conversations over the phone. This is a real skill and something I have definitely learnt a lot about in the recent months.

Tom: I would echo what Adam has said-restricting families from seeing their unwell loved ones goes against all our instincts as healthcare workers. This has been one of the greatest sources of distress among my colleagues, both nurses and doctors, and knowing it is the right thing to do does not necessarily make it feel right at the time.

\section{ANY PARTICULAR SURPRISES?}

Adam: Something that surprised and concerned me was the significant reduction in the number of patients without COVID presenting to hospital. The number of patients with myocardial infarctions, upper GI bleeds, strokes and similar presentations that usually fill the acute medical take were significantly reduced. I worry that the 'stay at home' message including the sheltered list may have deterred people from attending hospital when they really needed too. Reassuringly we are beginning to see those patients start to trickle in again.

Tom: Redeployment has reshuffled the junior doctors in the hospital. Suddenly we are speaking to junior colleagues from other specialities whom we have never worked alongside before. We are finding that we share many of the same challenges and that we can support each other with them. I hope that an unexpected upshot of the crisis will be renewed cohesion among the junior doctor body and engagement with junior doctor representation.

\section{ARE YOU SEEING ANY BEHAVIOURS FROM COLLEAGUES THAT ENCOURAGE OR INSPIRE YOU?}

Adam: I have found that this experience has been a remarkable leveller. A real sense of community has developed amongst the staff. What is so encouraging is how everyone is getting stuck in and the sense of camaraderie. It is so great to see those groups of staff in the hospital who are often overlooked-the cleaners, catering staff, porters-getting the recognition that they deserve from us their colleagues.

Tom: I have been utterly inspired by the resolute approach taken by my nursing colleagues as they face long shift after long shift, involving wearing uncomfortable PPE for hours at a time. We doctors may be donned for the duration of a procedure or a ward round, but the nurses in intensive care really don't leave their patients' sides and it speaks volumes of their dedication that so many uncomplainingly spend hours in those claustrophobic masks and sweltering gowns. Specialised intensive care nurses have risen to the task of supervising and guiding those nurses from other backgrounds (eg, scrub nurses, ward nurses, ED nurses, dental nurses) who have joined them over recent weeks. As many other redeployed doctors have done, I filled in a nursing shift when they had gaps and found first hand that the ITU nurse supervising meherself only 6 months into her job-did so with boundless patience and kindness.

\section{HOW ARE YOU MAINTAINING KINDNESS AND COMPASSION?}

Adam: The support from the public has been overwhelming and is really uplifting when you are having a bad day. Many local businesses, big and small, have been donating gifts to support the staff. I am so grateful for these outpourings of generosity. One of our staff nurses even received chocolates from Harry Kane and his family which caused quite a stir of excitement, particularly from me as a Tottenham fan!

Tom: In some ways compassion has driven innovation. Empathy with families who desperately wanted to see their relatives, but could not visit them in hospital, has led to an iPad scheme where tablets donated to the hospital are used to reconnect families virtually. Meanwhile, the desire to keep families fully updated despite the large numbers of patients has led to the development of a dedicated communication team to ensure that families are given regular updates and opportunities to ask questions. Not only has this been beneficial to patients and their relatives, but has also been a great reassurance to staff who have struggled with visitors not being allowed in hospital.

\section{ARE THERE ANY IDEAS OR READINGS THAT YOU FIND HELPFUL, FOR INSPIRATION AND SUPPORT, WHICH YOU WOULD RECOMMEND TO OTHERS?}

Adam: There has almost never been so much public interest in epidemiology and statistics. A brilliant and accessible book for understanding how to think about these things and how to avoid common biases is 'Factfulness' by Hans Rosling. In contrast, if you are looking for pandemic-themed periapocalyptic fiction I would definitely recommend Station Eleven by Emily St John Mandel.

Tom: Atul Gawande's 'Being Mortal'-it prompts us all to have vital conversations about the end of life and what is really important to us as individuals. It has never been more relevant. Also, David Nott's 'War Doctor' is a deeply moving account of what it is like to work as a surgeon in conflict and crises in the world's most austere healthcare environments. I would thoroughly recommend it at any time, but right now it has a special relevance. For those of us involved in crisis response for the first time, this book illustrates the good that can be achieved in even the most overwhelming circumstances. Nott's frank description of the psychological burden on his work should encourage us all to be mindful of how this current crisis may be affecting our own mental health, and that of our colleagues.

\section{WHAT ARE YOU LOOKING FOR FROM YOUR LEADERS?}

Adam: As the situation evolves it's really important we get clear communication about how things are changing from the Trust leadership. Similarly it is important that they listen to feedback from those working on the ground to what is and isn't working.

Tom: I would agree that a willingness to listen is critical. Putting in place robust strategies for getting regular and frank feedback from all members of staff involved in this effort, as well as from patients and their families, is key to ensuring our responses continue to be effective.

\section{Adam Harvey-Sullivan, ${ }^{1}$ Thomas Bernard Sullivan, ${ }^{2}$ Peter Sullivan ${ }^{3}$ \\ ${ }^{1}$ London School of Hygiene and Tropical Medicine, London, UK \\ ${ }^{2}$ Surgery, Royal London Hospital, London, UK \\ ${ }^{3}$ Department of Paediatrics, University of Oxford, Oxford, UK}

\section{Correspondence to}

Professor Peter Sullivan, Department of Paediatrics, University of Oxford, Oxford OX1 2JD, UK; peter.sullivan@paediatrics.ox.ac.uk 
Twitter Peter Sullivan @PeterSu42782101

Funding The authors have not declared a specific grant for this research from any funding agency in the public, commercial or not-for-profit sectors.

Competing interests None declared.

Patient consent for publication Not required.

Provenance and peer review Not commissioned; internally peer reviewed.

Data availability statement No data are available. This contribution does not include data. It is a narrative account.

This article is made freely available for use in accordance with BMJ's website terms and conditions for the duration of the covid-19 pandemic or until otherwise determined by BMJ. You may use, download and print the article for any lawful, non-commercial purpose (including text and data mining) provided that all copyright notices and trade marks are retained.

(c) Author(s) (or their employer(s)) 2020. No commercial re-use. See rights and permissions. Published by BMJ.

\section{D) Check for updates}

To cite: Harvey-Sullivan A, Sullivan TB, Sullivan P. BMJ Leader 2020:4:251-253.

Received 27 May 2020

Accepted 29 May 2020

Published Online First 17 June 2020

BMJ Leader 2020:4:251-253.

doi:10.1136/leader-2020-000301 